\title{
Selection Process of Supervisor for Doctoral Dissertation Using Analytical Network Process (ANP): An Iranian Study
}

\author{
Mansour Momeni \\ Associated Professor of Tehran University, Tehran. Iran \\ E-mail: mmomeni@ut.ac.ir \\ Behnaz Samimi \\ Business Management, Tehran University, Tehran, Iran \\ Mohammad Ali Afshari (Corresponding author) \\ Operations Management, Kar University, Qazvin, Iran \\ E-mail: mohamadaliafshari@yahoo.com \\ Mohammad Hasan Maleki \\ Operations Research, Tehran University, Tehran, Iran \\ Javad Mohammadi \\ Marketing, Tehran University, Tehran, Iran \\ E-mail: javadmohammadi10426@yahoo.com
}

Received: February 19, $2011 \quad$ Accepted: April 12, $2011 \quad$ doi:10.5430/jms.v2n2p63

\begin{abstract}
One of the most critical activities that the PhD. Student maybe faced is selecting supervisor for her dissertation. Most often these decisions are in the form of a selection problem from a finite number of choices. The selection is based on a set of criteria, such as professors' reputation, knowledge, and matching of interests among others. However, the application of these criteria in selecting a supervisor is often done in an unplanned manner, which can become one of the reasons for regret, lack of motivation, and poor quality of research output.

The need for having a supervisor who fits well with the students' preferences can hardly be overemphasized. The basic assumptions in this study, is that the criterions have relationships with each others. So the AHP method could not be a good way for evaluating the problem.

The paper aims to demonstrate the use of analytical network process (ANP) in the selection of a thesis supervisor. A survey of doctoral students is conducted to obtain a list of criteria that are significant for selection of a research guide and then modeled as an ANP problem. A survey of junior and senior doctoral students in Tehran University is also conducted to ascertain the relative weights of the criteria elements to demonstrate the application of the proposed method.
\end{abstract}

Keywords: Thesis supervisor, Doctoral dissertation, Analytical network process, Doctoral students, Multiple criteria

\section{Introduction}

Selection process of Doctoral Supervisor is one of the most important factors influence on successful completion of educations course. Guidance of academic supervisor is a major determiner of quality in a doctoral dissertation and in this reason this is deserve for pay attention. Unfortunately as Armstrong, Allison \& Hayes (2004) argue, this case still seriously overlook by researchers. 
Several problems, such as poor completion rates of research degrees (Burnett, 1999) and delayed completion of thesis (Garcia, Malot, \& Brethower, 1988), have been found in work related to thesis in postgraduate and higher levels of education.

For example, Rudd (1985) found that in UK $40 \%$ to $50 \%$ of post graduate students failed to complete their dissertation in social sciences. The quality of supervision has been often indicated as the main reason for these problems (Dillon \& Malott, 1981; Zoia, 1981). Students have expressed dissatisfaction with the process of supervision (Hockey, 1991) with reasons for dissatisfaction, which include poor direction and structure (Acker, Hill, \& Black, 1991), allocation to a supervisor with interests not matching with those of the student, and insufficient guidance and time scaling (Eggleston \& Delamont, 1983; Wright and Lodwick, 1989). Such dissatisfaction rates have been found to be higher in the domain of social sciences than in natural sciences (Young, Fogarty \& McRea, 1987).

In a study of the research supervision process for postgraduate students, Eggleston and Delamont (1983), found that the matching of student to supervisor for effective relationships is crucially important. The question that arises is how can this match between student and supervisor be made? In a doctoral level program, the student chooses a supervisor and has to develop a relationship with this individual.

This relationship is different in many ways from the relationships that students have had with the lecturers who delivered most of the courses. For example, research students do need guidance, but they also need to develop sufficient autonomy and freedom to design and execute their own projects (Cornwall, Schmithals, \& Jaques, 1977; Harding, 1973). Clearly, there are several qualities that a student expects to see in her research supervisor, all of which may or may not be of equal significance to the student(Ray, 2007). Consequently, the process of selection of the supervisor becomes one of the critical factors in determining the degree of fit between the student and her supervisor.

\section{Methodology of Research}

This study was conducted in two phases. The first phase may be described as the formulation phase where the basic selection problem was formulated as a multi criteria decision making problem. The second phase was the demonstration phase where the formulated problem was actually applied on a set of participants in the study to come out with conclusions for the larger audience of future research students. The questionnaire resulted an initial list of 20 items. After the list shortened to 12 elements that serve as the criteria for selection.

In the second phase, for each faculty sample, two groups of five students were randomly selected for a questionnaire survey. One group consisted of students we refer them as "junior students" which had not yet selected their supervisor, and the other group which we name them "senior students" which had already selected their supervisor

The questionnaire was included the pair wise comparisons of elements identified in first phase. Naturally, senior students were asked to rate the pairs based on what they considered in selection of their supervisors, and junior students were asked to rate them on basis of what they feel is important to them in such selection. The AHP formulation for both these groups was used and differences between two groups in each faculty separately noted. The finding has offered in Section of Results.

\section{Supervisor Selection Criteria}

Some of the criteria students imply are according to literature review, such as "can take a stand", or "Freedom to work". But a detailed set that students consciously use in selecting a supervisor is rarely documented. The faculties' students had a kind of convergence in their factors, so that most of criteria were the same, but in different words. Table 1 presents the final set of 12 factors after refine the words and enacting the proper name for them and offering the operational definition set for them.

\section{$<$ Table 1 about here $>$}

Most often supervisor selection happens based on input from senior doctoral students and one's own understanding of various strengths of the faculty members. The academy of management's doctoral students' liaison committee mentions three key elements to be considered when selecting a dissertation committee: expertise and interest in the topic pursued by the student, contacts with academic and other organizations where one wishes to end up working post dissertation, and good interrelationship between committee members. At a broad level, these elements do cover a majority of the concerns in supervisor selection and most doctoral students do consider them while selecting a thesis supervisor, however a detailed set that students consciously use in selecting a supervisor is rarely documented. To obtain comprehensive selection criteria, the doctoral students at the authors' institute were asked to list all issues they would consider or recommend one should consider before selecting a thesis supervisor. Table 1 presents the final set of 12 key elements after suitably rewording some of the elements and dropping some that conveyed the same meaning. 


\section{Analytical Network Process (ANP)}

Analytic hierarchy process (AHP) is one of the widely used approaches to handle such a multicriteria decision-making problem. However, a significant limitation of AHP is the assumption of independency among various criteria of decision-making. Analytic network process (ANP), on the other hand, captures interdependencies among the decision attributes and allows a more systematic analysis. It also allows inclusion of all the relevant criteria (tangible or intangible, objective or subjective, etc.) that have some bearing in arriving at the best decision (Saaty,1996).

Contrary to AHP, ANP provides a more generalized model in decision-making without making assumptions about the independency of the higher-level elements from lower-level elements and also of the elements within a level. Despite all these merits, the applications of ANP are not very common in a decision-making problem. However, in recent years, there has been an increase in the use of ANP in multi-criteria decision-making problems(Sanjay Jharkhariaa, Ravi Shankar,2007).

The steps to run the ANP is coming as below (Chung et al, 2006):

Step 1: Model construction and problem structuring: the problem should be stated clearly and decomposed into rational system like network. The structure can be obtained by the opinion of decision makers through brainstorming or other appropriate methods.

Step 2: Pairwise comparisons matrices and priority vectors: In ANP, like AHP, decision elements at each component are compared Pairwised with respect to their importance towards their control criterion, and the components themselves are also compared pairwise with respect to their contribution to the goal. Decision makers are asked to respond to a series of pairewise comparisons where two elements or two components at a time will be compared in terms of how they contribute to their particular upper level criterion(Meade and Sarkis, 1999). The relative values are determined with Saaty's 1-9 scale (Table 1), where a score of 1 represents equal importance between the two elements and a score 9 indicates the extreme importance of one element (row component in the matrix) compared to the other one (column component in the matrix) (Meade and Sarkis, 1999).

$<$ Table 2 about here $>$

Like AHP, pairewise comparison in ANP is made in the framework of a matrix, and a local priority vector can be derived as an estimate of relative importance associated with the elements (or components) being compared by solving the following equation:

$$
W_{n}=\left[\begin{array}{ccc}
0 & 0 & 0 \\
w_{21} & w_{22} & 0 \\
0 & w_{32} & I
\end{array}\right] A \times w=\lambda_{\max } \times w
$$

Where $A$ is the matrix of pairewise comparison, w is the eigenvector, $\lambda_{\max }$ is the largest eigen value of $A$.

Step 3: Supermatrix formatioan: the supermatrix concept is similar to the Markov chain process (Saaty, 1996). To obtain global priorities in a system with interdependent influences, the local priority vectors are entered in the appropriate columns of a matrix. As result, a supermatrix is actually a partitioned matrix, where each matrix segment represent a relationship between two nodes (components or clusters) in a system (Meade and Sarkis,1999). Let the components of a decision systems be $C_{k}, \mathrm{k}=1,2, \ldots, \mathrm{n}$, and each component $\mathrm{k}$ has $m_{k}$ elements, denoted by $e_{k 1}, e_{k 2}, \ldots,{ }^{e_{k m k}}$. The local priority vectors obtained in step 2 are grouped and located in appropriate positions in a supermatrix based on the flow of influence from a component to another component, or from a component to itself as in the loop. A standard form of a supermatrix is as in below:

As an example, the super matrix representation of a hierarchy with three levels as shown in figure 2 (a), is follows (Saaty, 1996).

$$
W_{h}=\left[\begin{array}{ccc}
0 & 0 & 0 \\
w_{21} & 0 & 0 \\
0 & w_{32} & I
\end{array}\right]
$$


where $w_{21}$ is a vector that represent the impact of the goal on the criteria, $w_{32}$ is a matrix that represent the impact of criteria on each of the alternatives, $I$ is the identity matrix, and entries of zeros corresponding to those elements that have no influence.

For the above example, if the criteria are interrelated among themselves, the hierarchy is replaced by a network as shown in Figure 2(b). the entry of $W_{n}$ given by ${ }^{w_{22}}$ would indicate the interdependency, and the supermatrix would be (Saaty, 1996).

$$
W_{n}=\left[\begin{array}{ccc}
0 & 0 & 0 \\
w_{21} & w_{22} & 0 \\
0 & w_{32} & I
\end{array}\right]
$$

\section{Research Formulation Structure}

The purpose of this empirical study is to investigate the problem of supervisor selection. First, we got an unweighted super matrix (figure5). With measure relation between every cluster in goal (supervisor selection) we got a weighted super matrix (figure6). In figure6 Social Network for conduct the research (.247) of communicative factor, Commitment (.085) and Convergence of Political Tendency (.083) of personal factor and Knowledge (.252) of scientific factor are critical value for supervisor selection.

As we could see in figure 3 the goal of problem is the selection of supervisor. Three levels exist in hierarchy. In the first level the goal is put; in the second level factors are seen and the third level is the alternative. In this case, for the sake of illustration, the student is considering only two faculty members as potential supervisors. This level can have as many alternatives as one wishes without the need to modify the process of obtaining the preference weights. The decision is made according to relative importance of elements for the student and the degree of fulfillment of the elements by each of the professors. In this case study, for solving the problem we use Super Decisions software.

The professor with highest total rating, which is obtained through a synthesis process, is the one to be selected. In figure 4 the best alternative is selected and it is supervisor A.

After getting weighted super matrix, limiting super matrix (figure7) is produced by limiting result of weighted matrix. In figure7, priorities of goal are found.

\section{Conclusion}

For a good academic activity, especially thesis writing, a good supervisor could bring a fresh and new idea in the mind of student. It is therefore important that the decision be made in as informed a manner as possible. In this paper a decision making model based on the ANP technique has been illustrated

for the selection of the most suitable professor for the role of thesis supervisor. Despite AHP, ANP ic considering the relations between criterions of model and could bring a better result than other MCDM technique.

In this paper we have illustrated the critical factors effecting on students selecting the supervisor. Figure6 Social Network for conduct the research (.247) of communicative factor, Commitment(.085) and Convergence of Political Tendency(.083) of personal factor and Knowledge(.252) of scientific factor are critical value for supervisor selection. It is hoped that the doctoral students can use this approach to validate their own tentative choice and be more confident about the decisions they have made or will make with regard to selecting their thesis supervisor. 


\section{References}

Acker, S., Hill, T., \& Black, E. (1994). Thesis Supervision in the social sciences: Managed or Negotiated? Higher Education, 28, 483-498.

Armstrong, S. J., Allison, C. W., \& Hayes, J. (2004). The effects of cognitive style on research supervision: A study of student-supervisor dyads in management education. Academy of Management Learning and Education, 3.

Burnett, P. (1999). The supervision of doctoral dissertation using a collaborative cohort model. Counselor Education and Supervision, 39(1), 46-52.

Cornwall, M. G., Schmithals, F., \& Jaques, D. (Eds.). (1977). What is project orientation? An overview. In Proceedings of the Seminar on Project Orientation in Higher Education, 1-16. University of Bremen,March 1976, University of London, Institute of Education.

Dillon, M. J., \& Malott, R. W. (1981). Supervising masters thesis and doctoral dissertations. Teaching and Psychology, $8(3), 195-202$.

Eggleston, J., \& Delamont, S. (1983). Supervision of students for research degrees. Birmingham, AL: BERA.

Forman, E. H., \& Gass, S. I. (2001). The Analytic Hierarchy Process--An exposition. Operations Research, 49(4). doi:10.1287/opre.49.4.469.11231, http://dx.doi.org/10.1287/opre.49.4.469.11231

Garcia, M. E., Mallot, R. W., \& Brethower, D. (1988). A system of thesis and dissertation supervision: Helping graduate students succeed, Teaching of Psychology, 7, 89-92.

Harding, A. G. (1973). The objectives and structure of undergraduate projects. British Journal of Educational Technology, 4, 216-232. doi:10.1111/j.1467-8535.1973.tb00616.x, http://dx.doi.org/10.1111/j.1467-8535.1973.tb00616.x

Hockey, J. (1991). The social science PhD - A literature review. Studies in Higher Education, 16(3), $319-332$.

Ray, S. (2007), Selecting a Doctoral Dissertation Supervisor: Analytical Hierarchy Approach to theMultiple Criteria Problem, International Journal of Doctoral Studies, 2, 23-32, doi:10.1080/03075079112331382875, http://dx.doi.org/10.1080/03075079112331382875

Rudd, E. (1985). A new look at post graduate failure. Guildford, England: SRHE and Slough: NFERNelson

Saaty, T. L. (1980). The Analytical Hierarchy Process. New York: McGraw Hill.

Saaty, T.L. (1996), Decision Making with Dependence and Feedback: The analytic network process, Pittsburgh: RWS Publications.

Saaty, T,L., (1980), The Analytic Hierarchy Process, McGraw-Hill, New York. Analytic Network Process, RWS Publications, Pittsburgh.

Sarkis, J., (2002/a), "Quantitative Models for Performance Management Systems-Alternate Considerations", International Journal of Production Economics, 86,81,90.

Wright, J., \& Lodwick, R. (1989). The process of the PhD: A study of the first year of doctoral study. ResearchPapers in Education, 4, 22-56. doi:10.1080/0267152890040103, http://dx.doi.org/10.1080/0267152890040103

Young, K., Fogarty, M. P., \& McRea, S. (1987). The management of doctoral studies in the social sciences.London, England: PSI.

Zoia, T. K. (1981). Completing long term undergraduate projects: Some critical variables. Unpublished masters thesis, Western Michigan University, Kalamazoo, MI. 
Table 1. Key elements considered in supervisor selection Element Description

\begin{tabular}{|c|c|c|}
\hline Factor & & Description \\
\hline Being Free & 1 & $\begin{array}{l}\text { Supervisor have enough free time to scrutiny and } \\
\text { guidance. }\end{array}$ \\
\hline $\begin{array}{l}\text { Convergence of Political } \\
\text { Tendency }\end{array}$ & 2 & $\begin{array}{l}\text { Supervisors have not political reputation, so that the } \\
\text { student being judged under such political tendency. }\end{array}$ \\
\hline Scientific Reputation & 3 & $\begin{array}{l}\text { Reputation of Supervisor in related field among } \\
\text { scientific society (some part of this criteria measure by } \\
\text { self-cognition and some part by lectures, books, in press) }\end{array}$ \\
\hline Personal Char & 4 & $\begin{array}{l}\text { Personal interest on characteristics of supervisor and feel } \\
\text { of comfort. }\end{array}$ \\
\hline $\begin{array}{l}\text { Social Network for conduct } \\
\text { the research }\end{array}$ & 5 & $\begin{array}{l}\text { The professor has good social network, so that ease the } \\
\text { conduct of dissertation in special places or facilitate } \\
\text { access to special persons. }\end{array}$ \\
\hline $\begin{array}{l}\text { Social Network for getting } \\
\text { job/opportunities }\end{array}$ & 6 & $\begin{array}{l}\text { The professor has such a good social network in } \\
\text { professional organizations that help student to get good } \\
\text { job offers or face with special opportunities. }\end{array}$ \\
\hline Comr & 7 & $\begin{array}{l}\text { The commitment supervisor have about quality and on } \\
\text { time completion of dissertation }\end{array}$ \\
\hline Convergence of Interests & 8 & $\begin{array}{l}\text { Both professor and student have same interests on the } \\
\text { field, so that both interestingly work on that. }\end{array}$ \\
\hline $\begin{array}{l}\text { Relationship with other } \\
\text { faculty members }\end{array}$ & 9 & $\begin{array}{l}\text { Professor has such a good relationship with other } \\
\text { members of faculty which facilitate the process of and } \\
\text { decrease the stringency on these. }\end{array}$ \\
\hline Knowledge & 10 & Real Knowledge about dissertation theme \\
\hline Can take a stand & 11 & $\begin{array}{l}\text { The extent to which the professor will support the } \\
\text { student in contentious situations, and defend his or her } \\
\text { stand once it has been agreed upon previously }\end{array}$ \\
\hline Flexibility & 12 & $\begin{array}{l}\text { Professor be so flexible to let the student conduct the } \\
\text { research according to his/her own perspective and not } \\
\text { forced to run it as the professor's willing. }\end{array}$ \\
\hline
\end{tabular}

Table 2. Saaty's 1-9 scales for AHP

\begin{tabular}{|c|c|}
\hline Definition & Intensity of importance \\
\hline Equal importance & 1 \\
\hline Moderate importance & 3 \\
\hline Strong importance & 5 \\
\hline Very strong importance & 7 \\
\hline Absolute importance & 9 \\
\hline Intermediate importance & $2,4,6,8$ \\
\hline
\end{tabular}




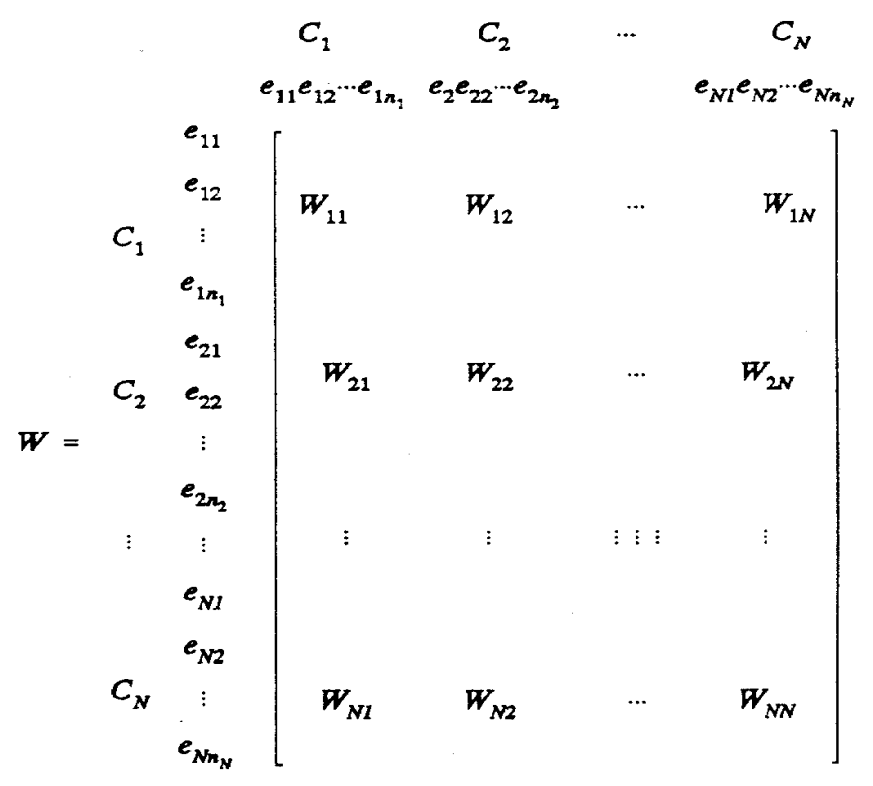

Figure1. Super matrix
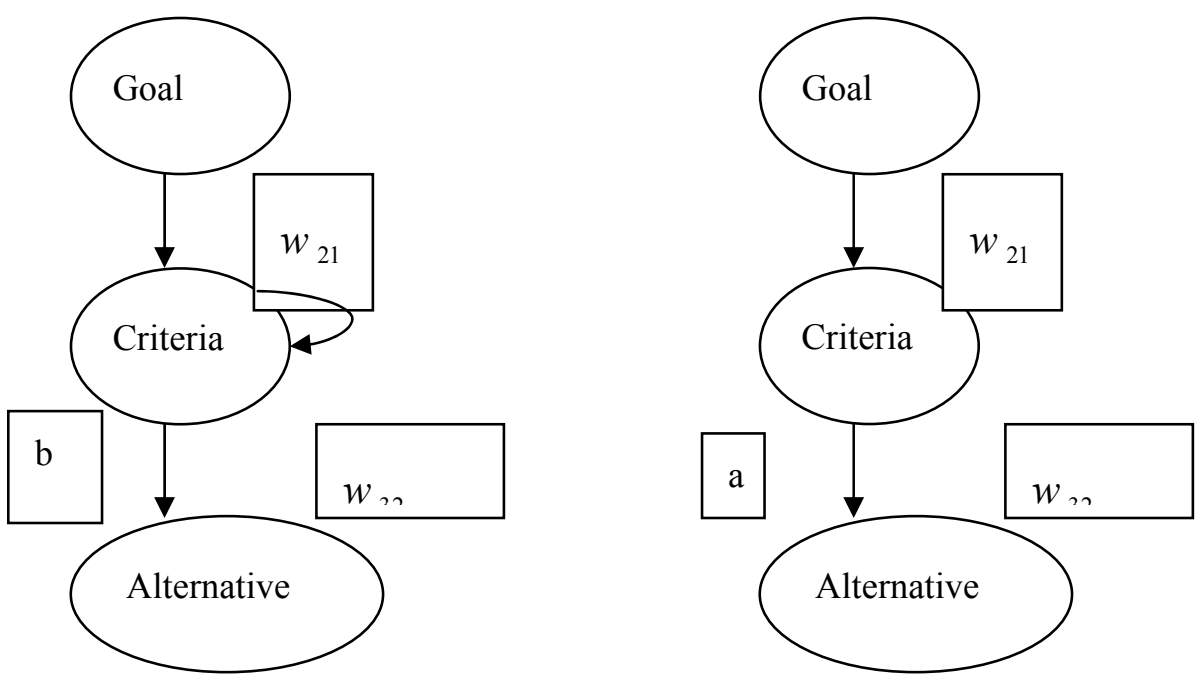

Figure 2. a: Network b: AHP (Chung et. Al., 2006; Momoh and Zhu,2003) 


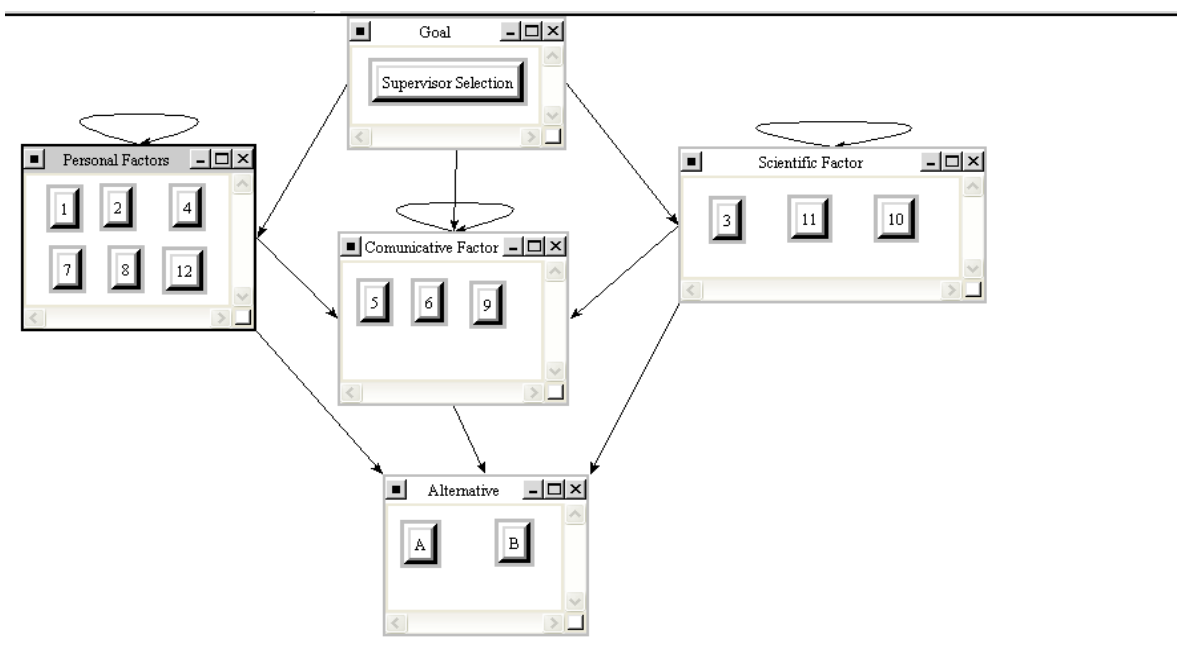

Figure3. Hierarchical Structure of Analytical Network Process for supervisor selection

\section{Alternative Rankings}

\begin{tabular}{|c|c|c|c|c|c|c|}
\hline Graphic & Alternatives & Total & Normal & Ideal & Ranking \\
\hline \hline & A & 0.4741 & 0.8533 & 1.0000 & 1 \\
\hline \hline & B & 0.0815 & 0.1467 & 0.1719 & 2 \\
\hline
\end{tabular}

Figure4. Alternative Rankings of Supervisor

\begin{tabular}{|c|c|c|c|c|c|c|c|c|c|c|c|c|c|c|c|c|c|}
\hline & \multicolumn{3}{|c|}{ Alternative } & \multicolumn{4}{|c|}{ Comunicative Factor } & \multicolumn{2}{|c|}{ Goal } & \multicolumn{3}{|c|}{ Personal Factors } & \multirow[b]{2}{*}{12} & \multirow[b]{2}{*}{3} & \multirow[b]{2}{*}{10} & \multirow{2}{*}{\multicolumn{2}{|c|}{11}} \\
\hline & f & A & $B$ & 5 & 6 & 9 & Supenisor & 1 & 2 & 4 & 7 & 8 & & & & & \\
\hline Alternative & & 0 & 0 & 0.166667 & 0 & 0 & 0 & 0.833333 & 0.5 & 0.166667 & 0.125033 & 0.6666667 & 0.9 & 0.166667 & 0.833333 & 0.888889 & \\
\hline & $B$ & 0 & 0 & 0.833333 & 0 & 0 & 0 & 0.166667 & 0.5 & 0.833333 & 0.874967 & 0.333333 & 0.1 & 0.833333 & 0.166667 & 0.111111 & \\
\hline Comunicat & 5 & 0 & 0 & 0.198581 & 0 & 0 & 0.742387 & 0 & 0 & 0 & 0 & 0 & 0 & 0.111111 & 0 & 0 & \\
\hline & 6 & 0 & 0 & 0.755762 & 0 & 0 & 0.046626 & 0 & 0 & 0 & 0 & 0 & 0 & 0.888889 & 0 & 0 & \\
\hline & 9 & 0 & 0 & 0.045656 & 0 & 0 & 0.210986 & 1 & 0 & 0 & 0 & 0 & 0 & 0 & 0 & 0 & \\
\hline Goal & Supenisor & 0 & 0 & 0 & 0 & 0 & 0 & 0 & 0 & 0 & 0 & 0 & 0 & 0 & 0 & 0 & \\
\hline Personal F & 1 & 0 & 0 & 0 & 0 & 0 & 0.087345 & 0.111111 & 0 & 0 & 0 & 0 & 0 & 0 & 0 & 0 & \\
\hline & 4 & 0 & 0 & 0 & 0 & 0 & 0.055658 & 0 & 0 & 0 & 0 & 0 & 0 & 0 & 0 & 0 & \\
\hline & 7 & 0 & 0 & 0 & 0 & 0 & 0.255452 & 0 & 0 & 0 & 0.8 & 0 & 0 & 0 & 0 & 0 & \\
\hline & 8 & 0 & 0 & 0 & 0 & 0 & 0.147585 & 0 & 0 & 0 & 0.2 & 0 & 0.111111 & 0 & 0 & 0 & \\
\hline & 12 & 0 & 0 & 0 & 0 & 0 & 0.204134 & 0.888889 & 0 & 0 & 0 & 0 & 0.888889 & 0 & 0 & 0 & \\
\hline Scientific F & 3 & 0 & 0 & 0 & 0 & 0 & 0.189174 & 0 & 0 & 0 & 0 & 0 & 0 & 1 & 0 & 0 & \\
\hline & 10 & 0 & 0 & 0 & 0 & 0 & 0.756788 & 0 & 0 & 0 & 0 & 0 & 0 & 0 & 0 & 0 & \\
\hline & 11 & 0 & 0 & 0 & 0 & 0 & 0.054038 & 0 & 0 & 0 & 0 & 0 & 0 & 0 & 0 & 0 & \\
\hline
\end{tabular}

Figure5. Unweighted super matrix 


\begin{tabular}{|c|c|c|c|c|c|c|c|c|c|c|c|c|c|c|c|c|c|}
\hline & & \multicolumn{2}{|l|}{ Alternative } & \multicolumn{4}{|c|}{ Comunicative Factor } & \multicolumn{2}{|c|}{ Goal } & \multicolumn{3}{|c|}{ Personal Factors } & \multirow[b]{2}{*}{12} & \multirow[b]{2}{*}{3} & \multirow[b]{2}{*}{10} & \multirow[b]{2}{*}{11} & \multirow{2}{*}{$\begin{array}{l}\text { Scient } \\
\end{array}$} \\
\hline & & A $\quad$ B & & 5 & 6 & 9 & Supervisor & 1 & 2 & 4 & 7 & 8 & & & & & \\
\hline Alternative & & 0 & 0 & 0.083333 & 0 & 0 & 0 & 0.277778 & 0.5 & 0.166667 & 0.062516 & 0.6666667 & 0.45 & 0.055556 & 0.833333 & 0.888889 & \\
\hline & B & 0 & 0 & 0.416667 & 0 & 0 & 0 & 0.055556 & 0.5 & 0.833333 & 0.437484 & 0.333333 & 0.05 & 0.277778 & 0.166667 & 0.111111 & \\
\hline \multirow[t]{3}{*}{ Comunicat } & 5 & 0 & 0 & 0.099291 & 0 & 0 & 0.247462 & 0 & 0 & 0 & 0 & 0 & 0 & 0.037037 & 0 & 0 & \\
\hline & 6 & 0 & 0 & 0.377881 & 0 & 0 & 0.015542 & 0 & 0 & 0 & 0 & 0 & 0 & 0.296296 & 0 & 0 & \\
\hline & 9 & 0 & 0 & 0.022828 & 0 & 0 & 0.070329 & 0.333333 & 0 & 0 & 0 & 0 & 0 & 0 & 0 & 0 & \\
\hline Goal & Supervisor & 0 & 0 & 0 & 0 & 0 & 0 & 0 & 0 & 0 & 0 & 0 & 0 & 0 & 0 & 0 & \\
\hline \multirow[t]{6}{*}{ Personal F } & 1 & 0 & 0 & 0 & 0 & 0 & 0.029115 & 0.037037 & 0 & 0 & 0 & 0 & 0 & 0 & 0 & 0 & \\
\hline & 2 & 0 & 0 & 0 & 0 & 0 & 0.083275 & 0 & 0 & 0 & 0 & 0 & 0 & 0 & 0 & 0 & \\
\hline & 4 & 0 & 0 & 0 & 0 & 0 & 0.018553 & 0 & 0 & 0 & 0 & 0 & 0 & 0 & 0 & 0 & \\
\hline & 7 & 0 & 0 & 0 & 0 & 0 & 0.085151 & 0 & 0 & 0 & 0.4 & 0 & 0 & 0 & 0 & 0 & \\
\hline & 8 & 0 & 0 & 0 & 0 & 0 & 0.049195 & 0 & 0 & 0 & 0.1 & 0 & 0.055556 & 0 & 0 & 0 & \\
\hline & 12 & 0 & 0 & 0 & 0 & 0 & 0.068045 & 0.296296 & 0 & 0 & 0 & 0 & 0.444444 & 0 & 0 & 0 & \\
\hline \multirow[t]{3}{*}{ Scientific F } & 3 & 0 & 0 & 0 & 0 & 0 & 0.063058 & 0 & 0 & 0 & 0 & 0 & 0 & 0.333333 & 0 & 0 & \\
\hline & 10 & 0 & 0 & 0 & 0 & 0 & 0.252263 & 0 & 0 & 0 & 0 & 0 & 0 & 0 & 0 & 0 & \\
\hline & 11 & 0 & 0 & 0 & 0 & 0 & 0.018013 & 0 & 0 & 0 & 0 & 0 & 0 & 0 & 0 & 0 & \\
\hline
\end{tabular}

Figure 6. Weighted super matrix

\begin{tabular}{|c|c|c|c|c|c|c|c|c|c|c|c|c|c|c|c|}
\hline & & Alternative & & \multicolumn{2}{|c|}{ Comunicative Factor } & \multicolumn{2}{|c|}{ Goal } & \multicolumn{3}{|c|}{ Personal Factors } & \multirow[b]{2}{*}{12} & \multirow[b]{2}{*}{3} & \multirow[b]{2}{*}{10} & \multirow{2}{*}{\multicolumn{2}{|c|}{ Scie }} \\
\hline & & B & 5 & 6 & 9 Superisor & 1 & 2 & 4 & 7 & 8 & & & & & \\
\hline Alternative & & 0 & 00.083333 & 0 & $0 \quad 0.474074$ & 0.474074 & 0 & & 183346 & & 0.474074 & $74 \quad 0.059351$ & 0 & 0 & \\
\hline & B & 0 & 00.416667 & 0 & $0 \quad 0.081481$ & 0.081481 & 0 & 0 & 116654 & 0 & 0.081481 & $\begin{array}{ll}81 & 0.296754\end{array}$ & 0 & 0 & \\
\hline \multirow[t]{3}{*}{ Comunicat } & 5 & 0 & $0 \quad 0.099291$ & 0 & 0 & 0 & 0 & 0 & 0 & 0 & & $0 \quad 0.045543$ & 0 & 0 & \\
\hline & 6 & 0 & $0 \quad 0.377881$ & 0 & 0 & 0 & 0 & 0 & 0 & 0 & & $0 \quad 0.307443$ & 0 & 0 & \\
\hline & 9 & 0 & 0.0022828 & 0 & 0 & 0 & 0 & 0 & 0 & 0 & & $0 \quad 0.003119$ & 0 & 0 & \\
\hline Goal & Supenisor & 0 & 0 & 0 & 0 & 0 & 0 & 0 & 0 & 0 & & 0 & 0 & 0 & \\
\hline \multirow[t]{6}{*}{ Personal $F$} & 1 & 0 & 0 & 0 & 0 & 0 & 0 & 0 & 0 & 0 & & 0 & 0 & 0 & \\
\hline & 2 & 0 & 0 & 0 & 0 & 0 & 0 & 0 & 0 & 0 & & 0 & 0 & 0 & \\
\hline & 4 & 0 & 0 & 0 & 0 & 0 & 0 & 0 & 0 & 0 & & 0 & 0 & 0 & \\
\hline & 7 & 0 & 0 & 0 & 0 & 0 & 0 & 0 & 0.32 & 0 & & 0 & 0 & 0 & \\
\hline & 8 & 0 & 0 & 0 & $0 \quad 0.049383$ & 0.049383 & 0 & 0 & 0.08 & 0 & 0.049383 & 0 & 0 & 0 & \\
\hline & 12 & 0 & 0 & 0 & $0 \quad 0.395062$ & 0.395062 & 0 & 0 & 0 & 0 & 0.395062 & 0 & 0 & 0 & \\
\hline \multirow[t]{3}{*}{ Scientific $F$} & 3 & 0 & 0 & 0 & 0 & 0 & 0 & 0 & 0 & 0 & & $0 \quad 0.287791$ & 0 & 0 & \\
\hline & 10 & 0 & 0 & 0 & 0 & 0 & 0 & 0 & 0 & 0 & & 0 & 0 & 0 & \\
\hline & 11 & 0 & 0 & 0 & 0 & 0 & 0 & 0 & 0 & 0 & & 0 & 0 & 0 & \\
\hline
\end{tabular}

Figure7. Limited Super Matrix 